\title{
ANALISIS FAKTOR-FAKTOR YANG MEMPENGARUHI MINAT BERWIRAUSAHA MAHASISWA DENGAN TEKNIK SEM
}

\author{
FATRIKA FAHMI, HAZMIRA YOZZA, IZZATI RAHMI HG \\ Program Studi Matematika, \\ Fakultas Matematika dan Ilmu Pengetahuan Alam, Universitas Andalas Padang, \\ Kampus UNAND Limau Manis Padang, Indonesia \\ fhy_fathica90@yahoo.com,hyozza@gmail.com,izzatirahmihg@yahoo.com
}

\begin{abstract}
Abstrak. Salah satu upaya pemerintah untuk menanggulangi masalah pengangguran adalah dengan menunjang terbentuknya usaha mandiri masyarakat. Salah satu perwujudan upaya tersebut adalah dengan meningkatkan minat kewirausahaan pada masyarakat terutama mahasiswa melalui berbagai kegiatan kewirausahaan. Banyak faktor yang melatarbelakangi tinggi rendahnya minat berwirausaha pada mahasiswa di antaranya karakteristik, lingkungan keluarga, lingkungan sekitar, kepribadian dan motif berwirausaha. Faktor-faktor tersebut ada yang dapat diukur secara langsung dan ada yang tidak. Salah satu analisis statistika yang dapat menganalisis hubungan faktor-faktor tersebut adalah Structural Equation Modeling (untuk selanjutnya, ditulis SEM). SEM dapat menganalisis hubungan antara peubah terukur dengan peubah tak terukur melalui analisis faktor konfirmatori dan hubungan antar faktor baik langsung ataupun tidak langsung melalui analisis jalur. Dari hasil analisis terhadap faktor-faktor yang melatarbelakangi tinggi rendahnya minat berwirausaha, diperoleh kesimpulan bahwa faktor yang paling berpengaruh terhadap minat berwirausaha mahasiswa Universitas Andalas adalah motif berwirausaha. Sedangkan faktor kedua yang paling berperan adalah lingkungan sekitar termasuk lingkungan pendidikan.
\end{abstract}

Kata Kunci: Minat berwirausaha, SEM, analisis faktor konfirmatori, analisis jalur, model pengukuran, model struktural

\section{Pendahuluan}

Banyak faktor yang melatarbelakangi tinggi rendahnya minat berwirausaha pada mahasiswa di antaranya karakteristik, lingkungan keluarga, lingkungan sekitar, kepribadian dan motif berwirausaha. Faktor-faktor tersebut ada yang dapat diukur secara langsung dan ada yang tidak. Salah satu analisis statistika yang dapat menganalisis hubungan faktor-faktor tersebut adalah SEM (Structural Equation Modelling). SEM dapat menganalisis hubungan antara peubah terukur dengan peubah tak terukur melalui analisis faktor konfirmatori dan hubungan antar faktor baik langsung ataupun tidak langsung melalui analisis jalur. Tujuan penelitian ini adalah untuk mengetahui faktor-faktor apa saja yang paling berpengaruh terhadap minat berwirausaha mahasiswa. Objek penelitian adalah mahasiswa S1 berstatus aktif di Universitas Andalas angkatan 2007-2009. 


\section{Landasan Teori}

\subsection{Analisis Faktor Konfirmatori [3]}

Dalam analisis faktor konfirmatori, model yang menggambarkan hubungan antara peubah terukur $X_{1}, X_{2}, \ldots, X_{k}$ dengan peubah tak terukur $F_{1}, F_{2}, \ldots, F_{r}$ disebut model pengukuran (measurement model). Perumusan model pengukuran ini berakar pada teori. Setelah model pengukuran dirumuskan, tahap selanjutnya dalam AFK adalah menentukan loading faktor masing-masing peubah $\left(l_{i}\right)$ yang menyatakan besarnya hubungan antara indikator dengan peubah latentnya. Penentuan loading faktor dapat dilakukan dengan metode kemungkinan maksimum. Setelah itu dilakukan pengujian model pengukuran yang terdiri dari:

(1) Uji kesesuaian model

(2) Uji kebermaknaan koefisien loading faktor : Uji validitas

(3) Evaluasi reliabilitas konstruktif

Setelah dilakukan pengujian model pengukuran, berdasarkan nilai loading faktor akan ditentukan skor komponen masing-masing peubah latent. Kemudian akan diperoleh nilai korelasi antar masing-masing peubah latent yang nantinya akan menjadi input dalam analisis jalur.

\subsection{Analisis Jalur [3]}

Dalam analisis jalur, hubungan antar peubah digambarkan dalam model struktural. Dari model struktural dapat dirumuskan persamaan struktural untuk selanjutnya dilakukan pendugaan koefisien jalur $\left(\rho_{i j}\right)$. koefisien jalur $\left(\rho_{i j}\right)$ menyatakan besarnya pengaruh suatu peubah eksogen terhadap peubah endogen dalam suatu model struktural. Dalam analisis jalur, koefisien jalur dapat diuraikan menjadi komponen pengaruh langsung dan tak langsung.

Selanjutnya dilakukan perhitungan koefisien determinasi berganda $\left(R^{2}\right)$ dan koefisien jalur galat $\left(\rho_{e}\right)$. Kemudian dilakukan uji $\mathbf{F}$ untuk mengetahui apakah peubah endogen dipengaruhi secara bersama-sama oleh peubah eksogen dan uji t untuk mengetahui apakah peubah eksogen berpengaruh secara individual terhadap peubah endogen. Apabila terdapat koefisien jalur yang tidak signifikan maka model diperbaiki melalui trimming yaitu dengan menghilangkan koefisien jalur yang tidak signifikan tersebut. Kemudian dilakukan uji kesesuaian model untuk mengetahui apakah hasil estimasi parameter model bisa diberlakukan terhadap populasi. Uji kesesuaian model biasa dilakukan dengan statistik uji Q.

\subsection{SEM (Structural Equation Modelling) [3]}

SEM (Structural Equation Modelling) merupakan gabungan dari dua teknik analisis multivariat yaitu analisis faktor konfirmatori dan analisis jalur.

(1) Peubah dan Model dalam SEM

Pada SEM, terdapat dua peubah yang akan diamati yaitu peubah latent yaitu peubah yang tidak dapat diukur langsung dan peubah manifest yaitu peubah 
yang dapat diukur langsung. Dalam SEM dikenal dua jenis model yaitu model pengukuran yaitu model yang menggambarkan hubungan antara peubah $l a-$ tent dengan peubah manifestnya dan model struktural yang menggambarkan hubungan antar peubah latent tersebut.

Berikut merupakan model lengkap SEM.

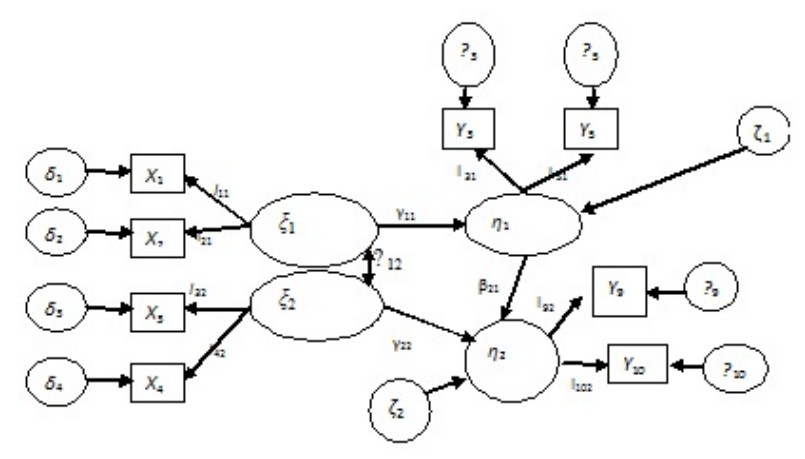

Gambar 1. Model Lengkap SEM

(2) Tahapan dalam SEM

a. Pengembangan model teoritis

b. Pengembangan diagram jalur

c. Konversi diagram jalur ke persamaan struktural dan pengukuran

d. Estimasi model pengukuran

e. Melakukan identifikasi model struktural

f. Estimasi model struktural

g. Perbaikan model

h. Interpretasi hasil

\subsection{Wirausaha dan Minat Berwirausaha [6]}

Minat berwirausaha tidak dibawa sejak lahir namun berkembang sesuai dengan faktor-faktor yang mempengaruhinya. Faktor-faktor yang mempengaruhi minat berwirausaha meliputi karakteristik (jenis kelamin dan usia), lingkungan (lingkungan keluarga, lingkungan pendidikan, lingkungan masyarakat), kepribadian (ektraversi, kesepahaman / Agreebleeness, berani mengambil resiko, kebutuhan berprestasi dan independen, evaluasi diri serta overconfidence / kepercayaan diri yang lebih) dan motif berwirausaha (bekerja dan penyaluran ide kreatif).

\section{Metodologi penelitian}

\subsection{Metode Pengumpulan Data}

Data pada penelitian ini diperoleh dari mahasiswa Universitas Andalas berstatus aktif angkatan 2007-2009 berupa kuisioner. Kuisioner yang digunakan dalam penelitian ini sudah melewati uji validitas dan uji reliabilitas. Uji validitas dilakukan den- 
gan menghitung koefisien korelasi antara masing-masing pernyataan dengan jumlah total pernyataan untuk peubah terkait dari responden ke- $i$, dengan $i=1,2 . ., \mathrm{n}$. Uji reliabilitas dilakukan berdasarkan koefisien alfa Cronbach $\left(C_{\alpha}\right)$. Menurut statistik alfa Cronbach $\left(C_{\alpha}\right)$, suatu instrument penelitian diindikasikan memiliki reliabilitas yang baik jika koefisien alfa Cronbach $\left(C_{\alpha}\right) \geq 0.70$.[4]

\subsection{Metode Pengolahan Data}

Peubah-peubah yang digunakan dalam penelitian ini adalah:

\begin{tabular}{|c|c|c|c|}
\hline & $\begin{array}{c}\text { Konstruk/ Peubah } \\
\text { Latent }\end{array}$ & $\begin{array}{c}\text { Indikator/ Peubah } \\
\text { Manifest }\end{array}$ & Peubah \\
\hline \multirow[t]{4}{*}{ Eksogen } & \multirow[t]{2}{*}{$\begin{array}{l}\text { Lingkungan Keluarga } \\
(\mathrm{LK})\end{array}$} & $\begin{array}{l}\text { Dukungan Keluarga Untuk } \\
\text { Berwirausaha }\end{array}$ & $\mathrm{X}_{1}$ \\
\hline & & Peranan Dalam Keluarga & $\mathrm{X}_{2}$ \\
\hline & \multirow[t]{2}{*}{ Lingkungan Sekitar (LS) } & $\begin{array}{l}\text { Dukungan Lingkungan } \\
\text { Pendidikan } \\
\end{array}$ & $\mathrm{X}_{3}$ \\
\hline & & $\begin{array}{l}\text { Dukungan Lingkungan } \\
\text { Pergaulan }\end{array}$ & $\mathrm{x}_{4}$ \\
\hline \multirow[t]{10}{*}{ Endogen } & \multirow[t]{6}{*}{ Kepribadian (KP) } & Ekstraversi & $\mathrm{Y}_{1}$ \\
\hline & & Agreebleeness & $\mathrm{Y}_{2}$ \\
\hline & & Berani Mengambil Resiko & $\mathrm{Y}_{3}$ \\
\hline & & $\begin{array}{l}\text { Kebutuhan Berprestasi \& } \\
\text { Independen }\end{array}$ & $\mathrm{Y}_{4}$ \\
\hline & & Evaluasi Diri & $\mathrm{Y}_{5}$ \\
\hline & & Overconfidence & $\mathrm{Y}_{6}$ \\
\hline & \multirow[t]{2}{*}{ Motif (MO) } & Bekerja & $\mathrm{Y}_{7}$ \\
\hline & & Penyaluran Ide Kreatif & $\mathrm{Y}_{8}$ \\
\hline & \multirow[t]{2}{*}{$\begin{array}{l}\text { Minat Berwirausaha } \\
\text { (MW) }\end{array}$} & \begin{tabular}{|l} 
Keterlibatan Dalam \\
Kegiatan Wirausaha \\
\end{tabular} & $\mathrm{Y}_{9}$ \\
\hline & & Mindset Masa Depan & $\mathrm{Y}_{10}$ \\
\hline
\end{tabular}

Tabel 1. Peubah dalam Penelitian

Berdasarkan teori yang telah mendapatkan justifikasi yang kuat, maka dibentuk diagram jalur sebagai berikut:

\section{Hasil dan Pembahasan}

\subsection{Estimasi Model Pengukuran}

Sebelum dilakukan analisis faktor, terlebih dahulu dilakukan uji KMO-MSA dan uji Barlett untuk mengetahui apakah data layak dianalisis lebih lanjut dengan analisis faktor. Selanjutnya akan ditentukan loading faktor dari masing-masing peubah latent terhadap indikatornya yang biasa dilakukan dengan estimasi maksimum likelihood. Berikut merupakan hasil estimasi model pengukuran terhadap peubah manifest endogen dan eksogen. 
Faktor-faktor yang Mempengaruhi Minat Berwirausaha Mahasiswa dengan Teknik SEM 9

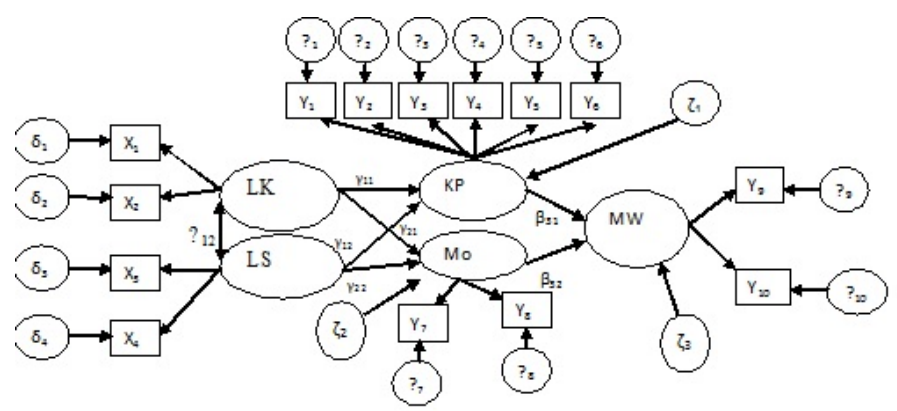

Gambar 2. Diagram Jalur Penelitian

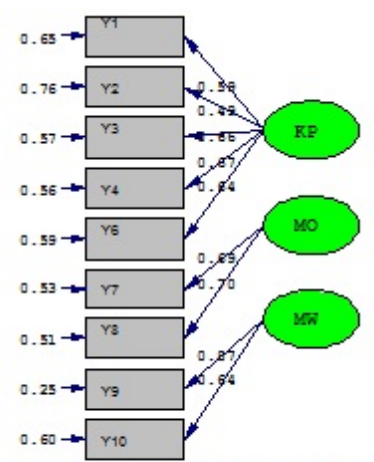

Chi-Square $=55.50, d f=24$, P-value $=0.00027$, RMSEA $=0.08$

Gambar 3. Estimasi Model Pengukuran Peubah Manifest Endogen

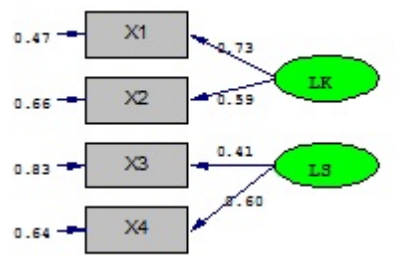

Chi-Square $=0.34, d f=1, P-v a l u e=0.56123$, RMSEA $=0.000$

Gambar 4. Estimasi Model Pengukuran Peubah Manifest Eksogen

Dalam estimasi model pengukuran dilakukan beberapa uji kesesuaian model. Berikut merupakan hasil uji kesesuaian model peubah manifest endogen dan eksogen. 


\begin{tabular}{|l|l|c|c|c|}
\hline No & Ukuran derajat kecocokan & Hasil uji & $\begin{array}{l}\text { Tingkt kecocokan yang bisa } \\
\text { diterima }\end{array}$ & Ket. \\
\hline 1 & $\begin{array}{l}\text { Root Mean Square Error of } \\
\text { Approximation (RMSEA) }\end{array}$ & 0.08 & $0.05 \leq$ RMSEA $\leq 0.08$ & Fit \\
\hline 2 & Goodness of Fit Index (GFI) & 0.94 & $\geq 0.90$ & Fit \\
\hline 3 & Comparative Fit Index (CFI) & 0.96 & $\geq 0.90$ & Fit \\
\hline 4 & Normed Fit Index (NFI) & 0.94 & $\geq 0.90$ & Fit \\
\hline
\end{tabular}

Tabel 2. Hasil Uji Kesesuaian Model Peubah Manifest Endogen

\begin{tabular}{|l|l|c|c|c|} 
No & Ukuran derajat kecocokan & Hasil uji & $\begin{array}{l}\text { Tingkt kecocokan yang } \\
\text { bisa diterima }\end{array}$ & Ket. \\
\hline 1 & $\begin{array}{l}\text { Root Mean Square Error of } \\
\text { Approximation (RMSEA) }\end{array}$ & 0 & $0.05 \leq$ RMSEA $\leq 0.08$ & $\begin{array}{c}\text { Belum } \\
\text { Fit }\end{array}$ \\
\hline 2 & Goodness of Fit Index (GFI) & 1 & $\geq 0.90$ & Fit \\
\hline 3 & Comparative Fit Index (CFI) & 1 & $\geq 0.90$ & Fit \\
\hline 4 & Normed Fit Index (NFI) & 1 & $\geq 0.90$ & Fit \\
\hline
\end{tabular}

Tabel 3. Hasil Uji Kesesuaian Model Peubah Manifest Eksogen

Secara keseluruhan, hasil uji kesesuaian menyatakan bahwa model sudah fit, artinya model mampu mengestimasi matriks kovarian antar peubah indikator populasi yang tidak berbeda dengan matriks kovarian data sampel.

\subsection{Identifikasi Model Struktural}

Identifikasi model struktural berdasarkan nilai derajat kebebasan $(d b)$ yaitu:

$$
\begin{aligned}
d b & =1 / 2(p+q)(p+q+1)-t \\
& =1 / 2(4+10)(4+10+1)-38 \\
& =67
\end{aligned}
$$

$p$ merupakan jumlah peubah eksogen yang terobservasi langsung, $q$ merupakan jumlah peubah endogen yang terobservasi langsung dan $t$ merupakan jumlah total parameter yang diobservasi.

Karena $d b>0$ maka disimpulkan model overidentified, artinya parameter yang ada di dalam model dapat diestimasi dari data yang diamati.

\subsection{Estimasi Model Struktural}

Berikut merupakan diagram hasil estimasi model struktural: 


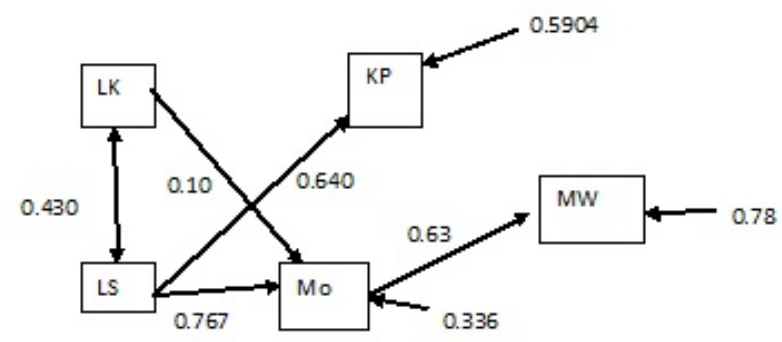

Gambar 5. Estimasi Model Struktural

\subsection{Pengujian Overall Model Fit}

Berikut merupakan pengujian keseluruhan model dengan statistik uji Q, yaitu:

$$
\begin{aligned}
Q & =\frac{1-R_{m}^{2}}{1-M} \\
& =\frac{1-0.882}{1-0.88} \\
& =0.983
\end{aligned}
$$

Karena $Q<1$, maka untuk menentukan fit tidaknya model adalah dengan statistik uji $W$, yaitu:

$$
\begin{aligned}
W & =-(n-d) \ln (Q) \\
& =3.378
\end{aligned}
$$

dengan $n$ merupakan ukuran sampel dan $d$ merupakan jumlah koefisien jalur yang tidak signifikan.

Karena $W \leq \chi_{0.05,2}^{2}$ maka tidak tolak $H_{0}$ sehingga hasil estimasi model dapat diberlakukan terhadap populasi.

\subsection{Pengaruh Langsung dan Tak Langsung}

(1) Pengaruh langsung

Dari hasil estimasi model struktural, diperoleh peubah-peubah yang dipengaruhi langsung oleh peubah lain, antara lain nilai peubah kepribadian (KP) dipengaruhi secara positif oleh lingkungan sekitar sebesar 40.96 persen sisanya merupakan pengaruh peubah lain di luar LS yang tidak terjelaskan model, nilai motif berwirausaha (MO) dipengaruhi secara positif oleh lingkungan keluarga (LK) dan lingkungan sekitar (LS), masing-masing sebesar 1 persen dan 58.82 persen, sisanya merupakan pengaruh peubah lain di luar LK dan LS yang tidak terjelaskan model dan nilai minat berwirausaha (MW) dipengaruhi secara positif oleh motif berwirausaha (MO) sebesar 39.69 persen, sisanya merupakan pengaruh peubah lain di luar MO yang tidak terjelaskan model. 
(2) Pengaruh tak langsung

Tinggi rendahnya minat berwirausaha (MW) dipengaruhi secara tidak langsung oleh lingkungan keluarga (LK) dan lingkungan sekitar (LS) melalui motif berwirausaha (MO) yaitu masing-masing sebesar 0.4 persen dan 23.04 persen.

\section{Kesimpulan}

Tinggi rendahnya minat berwirausaha dipengaruhi langsung secara positif oleh motif berwirausaha. Tinggi rendahnya minat berwirausaha juga dipengaruhi secara tidak langsung oleh lingkungan keluarga dan lingkungan sekitar melalui motif berwirausaha. Dilihat dari pengaruh total, peubah motif berwirausaha memiliki pengaruh paling besar terhadap peubah minat berwirausaha dan lingkungan sekitar merupakan pengaruh kedua terbesar terhadap minat berwirausaha.

\section{Ucapan Terimakasih}

Terimakasih kepada Ibu Dr. Maiyastri, M.Si, Bapak Dr. Dodi Devianto, Bapak Dr. Admi Nazra selaku penguji yang telah memberikan kriktik, saran dan pikirannya sehingga makalah ini dapat diselesaikan dengan baik.

\section{Daftar Pustaka}

[1] Anonim. 2012. Badan Pusat Statistik. http://www.bps.go.id (tanggal akses: 12 Mei 2012)

[2] Cholisi, F. 1991. Pengaruh Latar Belakang Keluarga Terhadap Motivasi Wirausaha dan Usaha Mandiri di kalangan mahasiswa ITS. Pusat Penelitian ITS, Surabaya

[3] Kusnendi. 2008. Model-Model Persamaan Struktural Satu dan Multigroup Sampel Dengan LISREL. Alfabeta, Bandung

[4] Mulyana, M. 2010. Analisis Pengaruh Faktor Personal Dan Lingkungan Eksternal Terhadap Minat Berwirausaha Mahasiswa STIE Kesatuan Bogor. Tesis S-2, Universitas IBN Khaldun, Bogor

[5] Nawangsari, A. Y.2011. Structural Equation Modelling pada Perhitungan Indeks Kepuasan Pelanggan dengan Menggunakan Software AMOS (Studi kasus : Perhitungan Indeks Kepuasan Mahasiswa FMIPA UNY Terhadap Operator IM3). Skripsi, Universitas Negeri Yogyakarta, Yogyakarta

[6] Yulia, W. 2010. Analisis Karakteristik Mahasiswa dan Faktor-Faktor yang Berpengaruh Terhadap Kepemilikan Usaha Mandiri Mahasiswa ITS. Skripsi, Jurusan Statistika FMIPA-ITS, Surabaya 